1. MBBS, FCPS (Cardiology) FACC (USA), Dip-CARD (Pb) Associate Professor Cardiology Faisalabad Institute of Cardiology, Faisalabad.

2. MBBS, FCPS (Cardiology) Assistant Professor of Cardiology, University of Medical \& Dental College, Faisalabad.

3. MBBS

Medical Officer,

Cardiology Department,

Faisalabad Institute of Cardiology, Faisalabad.

Correspondence Address: Dr. Naeem Asghar MBBS, FCPS (Cardiology) Assistant Professor of Cardiology, University of Medical \& Dental College, Faisalabad.

dearnaeem06@gmail.com

Article received on: 09/08/2016

Accepted for publication: 15/10/2016

Received after proof reading: $14 / 11 / 2016$

\section{ASYMPTOMATIC DIABETICS; DIASTOLIC DYSFUNCTION dearnaeem06@gmail.com}

\author{
Dr. Liaqat Ali', Dr. Naeem Asghar ${ }^{2}$, Dr. Imran Khan ${ }^{3}$
}

ABSTRACT... Background: Diabetes mellitus (DM) is not only a significant independent risk factor for developing of atherosclerotic ischemic heart disease or ventricular hypertrophy but it is also able to trigger a diabetic cardiomyopathy due to dysmetabolic processes resulting heart failure. Cardiovascular complications are known to be the main cause of death and morbidity in diabetic patients. Objectives: How frequent is the diastolic dysfunction in asymptomatic diabetic? Study Design: Descriptive cross sectional. Setting: Echocardiography department Faisalabad Institute of Cardiology Faisalabad. Patients were recruited from outpatient department of Faisalabad institute of cardiology Faisalabad. Duration of Study: Six months from: 28-06-2015 to 28-12-2015. Methodology: 200 patients were included in the study. Patient's bio data was recorded and informed consent was taken. All echocardiographic studies were performed with VIVID-07 echo machine by the same operator. Detailed assessment of left ventricular systolic and diastolic function by using standard 2-dimensional, color flow Doppler and tissue Doppler imaging (TDI) was done. Images were obtained in all patients. Each patient underwent left ventricular (LV) diastolic function assessment by conventional Doppler, tissue Doppler imaging (TDI). LV ejection fraction was calculated using conventional method. Blood flow velocities at mitral valve leaflets and pulmonary veins were recorded with averaged from 3 end-expiratory cycles at a sweep of $100 \mathrm{~mm} / \mathrm{s}$. This information was collected through a specially designed proforma by the author. Results: In our study, out of 200 cases, $52 \%(n=104)$ were between 50 55 years of age while $48 \%(n=96)$ were between $56-60$ years of age, mean + sd was calculated as $55.54+2.59$ years, $49 \%(n=98)$ were male while $51 \%(n=102)$ were females, frequency of diastolic dysfunction in asymptomatic, normotensive patients with diabetes mellitus was recorded as $45.5 \%(n=91)$ while $54.5 \%(n=109)$ had no findings of the morbidity. Conclusion: We conclude that the frequency of diastolic dysfunction is quite high (45.5\%) in asymptomatic diabetics.

Key words: $\quad$ Type II diabetes mellitus, normotensive, diastolic dysfunction

Article Citation: Ali L, Asghar N, Khan I. Asymptomatic diabetics; diastolic dysfunction. Professional Med J 2016;23(11):1373-1376. DOI: 10.17957/TPMJ/16.3569

\section{INTRODUCTION}

Patients with diabetes mellitus are high risk for cardiovascular deaths even diabetic women have greater risk than non-diabetics. ${ }^{1}$ International Diabetic Federation indicated significant increase number of diabetic. ${ }^{2}$

Cardiac disease in diabetes mellitus consists of both vascular and myocardial abnormalities. The latter are characterized predominantly by diastolic dysfunction. ${ }^{3}$ Diastolic dysfunction is an early sign of diabetic cardiomyopathy. ${ }^{4}$ Myocardial diastolic dysfunction with normal systolic function causes exertional symptoms in type 2 diabetic subjects may lead to heart failure require an aggressive treatment. ${ }^{5,6}$
High prevalence of diastolic dysfunction in diabetic best assessed with echocardiography. ${ }^{7,8}$ However different studies documented different prevalence of diastolic dysfunction in diabetics. ${ }^{9,10}$

The objective of this study is to estimate the frequency of diastolic dysfunction in asymptomatic diabetics by Doppler echocardiography in our population. Literature has reported controversial results as one study has reported low frequency while other reported it to be high. Moreover, previous studies were conducted on small sample size. ${ }^{9-10}$ we will conduct this study on relatively large sample size to gain more precise results. This will help for early detection of heart failure in diabetic patients. 


\section{OBJECTIVE}

How frequent is the diastolic dysfunction in asymptomatic diabetic?

\section{OPERATIONAL DEFINITION}

\section{Diastolic Dysfunction}

All of the followings echocardiographic criteria was used for Diastolic dysfunction.

- Mitral valve E/A ratio less than 1 or greater than 2.

- Mitral valve Deceleration time (DT) less than 160 or greater than 240 (msec).

- Isovolumic relaxation time (IVRT) less than 60 or greater than 90 (msec).

- Tissue Doppler imaging velocity (eTDI) at septal and lateral mitral annulus less than 8 $(\mathrm{cm} / \mathrm{s})$.

- $\quad$ The pulmonary vein S/D less than 1.

\section{ASYMPTOMATIC PATIENTS}

- The patients having no cardiac symptoms i.e. chest pain, shortness of breath, peripheral edema (swelling of feet) on the basis of history.

\section{Diabetes mellitus}

- It is defined as presence of FBS $>126 \mathrm{mg} /$ dl and RBS $>186 \mathrm{mg} / \mathrm{dl}$ on consecutive two readings and patient is taking anti-diabetic drugs for one year.

\section{MATERIALS AND METHODS \\ Study Design \\ Descriptive cross sectional.}

\section{Setting}

Echocardiography department Faisalabad Institute of Cardiology Faisalabad.

\section{Duration of Study}

Six months after approval of synopsis.

From: 28-06-2015 to 28-12-2015

\section{Sample Size}

By using WHO sample size calculator.

$P=48 \% 10$

Confidence level $=95 \%$

Absolute precision required $=7 \%$

Sample size $=200$

\section{Sampling Technique}

Non probability consecutive sampling.

\section{Inclusion Criteria}

1. Patients having at least one year history of diabetes mellitus insulin and non-insulin dependent.

2. Patients 50 to 60 years of age, including both genders.

3. Asymptomatic, normotensive patients with diabetes mellitus as per operational definition.

\section{Exclusion Criteria}

1. Evidence of coronary, valvular, congenital heart disease, myocardial, infiltrative pericardial or pulmonary disease.

2. Diabetic patients with complications like Nephropathy, Neuropathy, and Retinopathy on history and available medical records.

\section{Data Collection Procedure}

200 patients were included in the study. Patient's biodata was recorded and informed consent was taken. All echocardiographic studies were performed with VIVID-07 echo machine by the same operator. Detailed assessment of left ventricular systolic and diastolic function by using standard 2-dimensional, color flow Doppler and tissue Doppler imaging (TDI) was done. images were obtained in all patients. Each patient underwent left ventricular (LV) diastolic function assessment by conventional Doppler, tissue Doppler imaging (TDI). LV ejection fraction was calculated using conventional method. Blood flow velocities at mitral valve leaflets and pulmonary veins were recorded with averaged from 3 end-expiratory cycles at a sweep of 100 $\mathrm{mm} / \mathrm{s}$. This information was collected through a specially designed proforma by the author.

\section{Data Analysis Procedure}

SPSS version 20.0 was used for data analysis. Qualitative variables i.e. age was presented as mean and standard deviations. Categorical variables i.e. gender was presented as frequencies and percentages. Presence and absence of diastolic dysfunction in diabetics was presented by calculating frequency and percentage. Effect modifiers like age and gender was controlled by 
stratification. Post-stratification chi-square test was applied. Significant P-value was less than 0.05 .

\section{RESULTS}

200 cases were enrolled in the study.

\section{Age Distribution}

Age distribution of the patients was done showing that majority of the patients were between 5055 years of age, mean +sd was calculated as $55.54+2.59$ years. (Table-l)

\begin{tabular}{|c|c|c|}
\hline Age (in years) & No. of patients & $\%$ \\
\hline $50-55$ & 104 & 52 \\
\hline $56-60$ & 96 & 48 \\
\hline Total & $\mathbf{2 0 0}$ & $\mathbf{1 0 0}$ \\
\hline \multicolumn{2}{|r|}{$\begin{array}{r}\text { Table-l. Age distribution }(\mathrm{n}=\mathbf{2 0 0}) \\
\text { Mean+sd: } 55.54+2.59\end{array}$} \\
\hline
\end{tabular}

\section{Gender Distribution}

Distribution of cases according to gender showing that majotity of the patients were females. (Table-II)

\begin{tabular}{|c|c|c|}
\hline Gender & No. of patients & $\%$ \\
\hline Male & 98 & 49 \\
\hline Female & 102 & 51 \\
\hline Total & $\mathbf{2 0 0}$ & $\mathbf{1 0 0}$ \\
\hline Table-Il. Gender distribution $(\mathbf{n = 2 0 0 )}$ \\
\hline
\end{tabular}

\section{Frequency of Diastolic Dysfunction}

Frequency of diastolic dysfunction in asymptomatic patients with diabetes mellitus was recorded as $45.5 \%(n=91)$. (Table-III)

\begin{tabular}{|c|c|c|}
\hline Diastolic dysfunction & No. of patients & $\%$ \\
\hline Yes & 91 & 45.5 \\
\hline No & 109 & 54.5 \\
\hline Total & $\mathbf{2 0 0}$ & $\mathbf{1 0 0}$ \\
\hline
\end{tabular}

Table-III. Frequency of diastolic dysfunction in asymptomatic patients with diabetes mellitus $(n=200)$

\section{Stratification}

Stratification for age and gender was calculated and presented in Table-IV \& V respectively.

\begin{tabular}{|c|c|c|c|}
\hline \multirow{2}{*}{$\begin{array}{c}\text { Age } \\
\text { (in years) }\end{array}$} & \multicolumn{2}{|c|}{ Diastolic Dysfunction } & \multirow{2}{*}{ P value } \\
\hline $50-55$ & Yes & No & \\
\hline $56-60$ & 53 & 51 & 0.10 \\
\hline
\end{tabular}

Table-IV. Stratification for frequency of diastolic dysfunction with regards to age

\begin{tabular}{|c|c|c|c|}
\hline \multirow{2}{*}{ Gender } & \multicolumn{2}{|c|}{ Diastolic Dysfunction } & \multirow{2}{*}{ P value } \\
\cline { 2 - 3 } & Yes & No & \\
\hline Male & 43 & 55 & \\
\hline Female & 48 & 54 & 0.65 \\
\hline
\end{tabular}

Table-V. Stratification for frequency of diastolic dysfunction with regards to gender

\begin{tabular}{|l|l|l|c|}
\hline \multicolumn{1}{|c|}{ Male } & \multicolumn{1}{|c|}{ Female } & P-Value \\
\hline E/A Ratio & $\begin{array}{l}0.90 \\
\text { SD } \pm 2.73\end{array}$ & $\begin{array}{l}0.94 \\
\text { SD } \pm 1.81\end{array}$ & 0.10 \\
\hline DT & $\begin{array}{l}251 \\
\text { SD } \pm 4.76\end{array}$ & $\begin{array}{l}244 \\
\text { SD } \pm 2.80\end{array}$ & 0.24 \\
\hline IVRT & 95 & 98 & 0.08 \\
\hline ETDI (Septal) & $\begin{array}{l}7.75 \\
\text { SD } \pm 0.20\end{array}$ & $\begin{array}{l}7.68 \\
\text { SD } \pm 0.13\end{array}$ & 0.32 \\
\hline ETDI (Lateral) & $\begin{array}{l}9.70 \\
\text { SD } \pm 0.22\end{array}$ & $\begin{array}{l}9.65 \\
\text { SD } \pm 18\end{array}$ & 0.45 \\
\hline E/e- & $\begin{array}{l}15.95 \\
\text { SD } \pm 0.56\end{array}$ & $\begin{array}{l}15.78 \\
\text { SD } \pm 0.37\end{array}$ & 0.10 \\
\hline \multicolumn{2}{|l|}{ Table-VI. Stratification for frequency of diastolic } \\
dysfunction with regards to gender
\end{tabular}

\section{DISCUSSION}

Diabetes is among the most common chronic disease in the world. The mounting incidence and prevalence of type 2 diabetes is related to increasing age, obesity and physical inactivity. Diabetics have more cardiovascular complications leading to death. In ambulatory setting diabetes is independently associated with two to five fold increased risk of heart failure over that in person without diabetes. Diabetes cause deposition of collagen and glycation end products in myocardium leading to left ventricular diastolic dysfunction resulting heart failure.

We was planned to determined frequency of asymptomatic diastolic dysfunction in diabetics 
by Doppler echocardiography. Literature has reported controversial results as one study has reported low frequency(48\%) while other reported it to be high $(63,2 \%)$. Moreover, previous studies have been conducted on small sample size. We conducted this study on relatively large sample size to gain more precise results.

In our study, out of 200 cases, $52 \%(n=104)$ were between $50-55$ years of age while $48 \%(n=96)$ were between 56-60 years of age, mean +sd was calculated as $55.54+2.59$ years, $49 \%(n=98)$ were male while $51 \%(n=102)$ were females, frequency of diastolic dysfunction in asymptomatic diabetics was recorded as $45.5 \%(n=91)$ while $54.5 \%(n=109)$ had no findings of the morbidity. These findings are comparable with several studies. ${ }^{7}$ Previous studies reported very high incidence $(63.2 \%) .^{9}$ Similarly Boyer et $\mathrm{al}^{10}$ reported high prevalence $(75 \%)$. However local studies have comparable prevalence (48\%) with our findings. ${ }^{11}$ Diastolic dysfunction is more often documented with TDI, these findings are also higher than reported in our study. This study confirms that diastolic dysfunction is more prevalent in diabetics.

\section{CONCLUSION}

We concluded that the frequency of diastolic dysfunction is quite high in asymptomatic patients with diabetes mellitus.

Copyright(C) 15 Oct, 2016.

\section{REFERENCES}

1. Unachkwa C, Ofori S, Diabetes mellitus and cardiovascular risk. Internet $J$ Endocrinol [Internet].2012; 7(1): Available from: https//ispub.com/ IJEN/7/1/14021.

2. Whiting DR, Guariquata L, Weil C, Shaw J, IDF diabetes atlas; global estimates of the prevalence of diabetes for 2011 and 2030. Diabetes Resclin Pract 2011;
$94: 311-21$.

3. Von Bibra H, Sutton MSJ. Diastolic dysfunction in diabetes and the metabolic syndrome: promising potential for diagnosis and prognosis. Diabetologia 2010;53:1033-45.

4. Roldan CA. The ultimate echo guide. $2^{\text {nd }}$ ed. London: Lippincott Williams \& Wilkins;2012.

5. Zahiti BF, Gorani DR, Gashi FB, Gjoka SB, Zahiti LB, Haxhiu BS. Left ventricular diastolic dysfunction in asymptomatic type 2 diabetic patients: detection and evaluation by tissue doppler imaging. Acta Inform Med. 2013;21:120-3.

6. Masugata H, Senda G, Goda F, Yoshihara Y, Yoshikawa $\mathrm{K}$, Fujita N. Left ventricular diastolic dysfunction in normotensive diabetic patients in various age strata. Diabetes Res Clin Pract. 2008; 79:91-6.

7. Poulsen KM, Henriksen JE, Dahl J, Johansen A, Gerke $\mathrm{O}$, Vach $\mathrm{W}$. Left ventricular diastolic function in type 2 diabetes mellitus: Prevalence and association with myocardial and vascular disease. Circ: Cardiovasc Imaging. 2010; 3:24-31.

8. Ciftel S, Icagasioglu S, Yildiz G, Tekin G, Aydin H. Association of left ventricular diastolic dysfunction with elevated NT-proBNP in type 2 diabetes mellitus patients with preserved ejection fraction: the supplemantary role of tissue doppler imaging parameters and NT-proBNP levels. Diabetes Res Clin Pract. 2012;96:179-86.

9. Exiara T, Konstantis A, Papazoglou L, Kouroupi M, Kalpaka A, Mporgi L. Left ventricular diastolic dysfunction in diabetes mellitus type 2: Pp. 17.147. J Hypertens. 2010;28:e294.

10. Boyer JK, Thanigaraj S, Schechtman KB, Pérez JE. Prevalence of ventricular diastolic dysfunction in asymptomatic, normotensive patients with diabetes mellitus. Am J Cardiol. 2004; 93:870-5.

11. Randhawa FA, Hussnain MT, Nazir S, Masud F. Frequency of diastolic dysfunction in asymptomatic, normotensive type-2 diabetic patients. J Ayub Med Coll Abbottabad. 2014;26(1):35-7.

\section{AUTHORSHIP AND CONTRIBUTION DECLARATION}

\begin{tabular}{|c|c|c|c|}
\hline Sr. \# & Author-s Full Name & Contribution to the paper & Author $=$ s Signature \\
\hline 1 & Dr. Liaqat Ali & $\begin{array}{l}\text { Concept and study design } \\
\text { Drafting }\end{array}$ & \\
\hline 2 & Dr. Naeem Asghar & $\begin{array}{l}\text { Data collection, crirical } \\
\text { revision of article }\end{array}$ & is \\
\hline 3 & Dr. Imran Khan & $\begin{array}{l}\text { Data interpretation and } \\
\text { analysis }\end{array}$ & Qhou. \\
\hline
\end{tabular}

